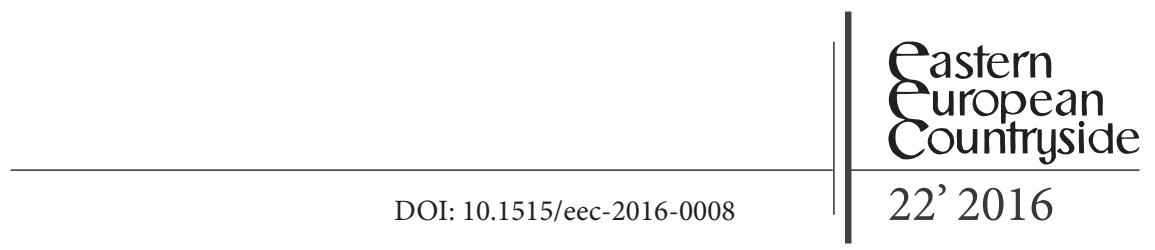

Piotr Nowak, Anna Jastrzębiec-Witowska, Krzysztof Gorlach

Jagiellonian University, Kraków, Poland

\title{
Cooperative Movements in Rural Areas in Contemporary Poland: \\ A Brief Comparison of Farmers' Attitudes of Members and Non-memebrs of Coooperatives
}

\begin{abstract}
In this paper the authors consider some issues concerning the problems of rural cooperatives in contemporary Poland. In the first part, the important role of cooperatives in agricultural changes as well as rural development has been stressed, especially as an opposition to neo-liberal tendencies in the food economy. In such a context, the authors would like to compare some opinions concerning cooperative movements presented by farmers who are members and non-members of cooperatives. The characteristics of respondents contain some information about their sex, age, level of education as well as ownership status, including also the size of the possessed farms. Moreover, the presentation of attitudes has been focussed on the issues of cooperation with other farmers as well as general trust in others. The issues of knowledge about cooperative ideas and contemporary cooperative movements have been taken into consideration. In the final part of the empirical analysis some opinions concerning major obstacles to the development of cooperative movements have been considered. To conclude the whole paper the authors stress some differences in opinions and attitudes between members and non-members of cooperatives. However, what seems to be even more important is that even farmers who are members
\end{abstract}


of cooperatives lacked sufficient knowledge on issues that make cooperatives successful.

Keywords: agriculture; farmers; rural areas; cooperative movements; attitudes

\section{Some introductory remarks}

Cooperatives are known to play a significant role in the socio-economic development of various countries all over the world. In the European Union, there are 235,000 cooperative enterprises which employ close to 4.5 million people and, to some extent, influence the lives of all 140 million inhabitants of Europe. Worldwide, one billion people belong to cooperatives, which is one seventh of the human population. Cooperatives are popular in affluent as well as developing countries. Poland and Germany each have around 3,000 cooperatives, with Poland's number of farms being close to 2.4 million and Germany having 370,000 farms. The membership in Polish agricultural cooperatives is that of 400,000 people, while in German cooperatives it is 1.8 million. This could be explained by the fact that the average German farmer belongs to more than four cooperatives, while in Poland a cooperative may attract one out of five farmers. A Swedish farmer is usually a member of four cooperatives and a Finnish farmer holds membership in three cooperatives. In Poland, only dairy cooperatives can be compared with those of Western Europe in terms of revenues, membership statistics, and modernisation (Malec 2013). The significance of the cooperative movement around the world is comparatively greater than in Poland. Cooperatives are obviously important for their members, who, as producers, are able to receive good income for their work, but their role in the food chain should not be undermined. Thanks to cooperatives, the costs of food production are lower and consumers can buy food products at more affordable prices. Farmers who are members of cooperatives are able to secure means of production at lower costs and sell their products at better prices while keeping a large portion of the added value of the product acquired by the consumer (Gutiérrez, Atela and Dueñas 2005; McKee, Wilson and Dahl 2014; Diaz-Foncea, Marcuello 2013; Chaddad, Cook 2004; Valentinov 2005).

The question of whether or not Polish agriculture has a chance of similar cooperative development to that of France or Denmark is therefore justified. 
The following paper aims at providing an overview of opinions that farmers who are members of cooperatives have regarding the development of the cooperative movement in rural Poland. The authors thought that it would be useful to juxtapose the opinions of two groups of respondents: farmers who have cooperative membership and non-member farmers. It is meant to address the question of whether farmers within cooperatives have adequate knowledge of them and if such knowledge could enable further development of cooperatives in Polish rural areas in the future.

Communities with strong cooperative experience tend to have a better chance of civil societal development. The cooperative movement teaches a certain way of collective thinking and acting with common goals in mind. Not without meaning is the shared responsibility for the cooperative estate and assets. In highly developed societies, the cooperative movement provides a powerful defence against neo-liberal favouring of large agricultural corporations. It helps to empower family farms and individual farmers who are faced with the tensions of industrial forms of food production (Mooney 2004).

\section{Some information about conducted research}

The research has followed the overall renaissance of knowledge concerning the idea of cooperatives as well as their perspectives in rural areas of Poland (see: Brodziński et al. 2015). Considerations in volume have been focused on some core issues containing the ideas of cooperatives as an important form of rural economy, some tendencies in the development of cooperative movement in contemporary Poland as well as some perspectives of cooperative movement in rural Poland. However, what seems to be especially important lies, in our opinion, in the area of cooperative movement evaluation by farmers and agricultural advisers, together with some practical justification of rural cooperatives.

Therefore, this particular research was conducted during a series of meetings with farmers and rural residents organised by extension specialists in the fall of 2013. A total of 2,525 questionnaires were completed by farmers across Poland, of whom 835 were cooperative members. The project entitled "Cooperatives in opinions of farmers and extension advisers and the role of cooperatives in the development of entrepreneurship in rural areas" 
(Contract: KSOW/82/09/2013) was conducted by the Agricultural Advisory Centre (Centrum Doradztwa Rolniczego) in Kraków. Some findings were already published in 2013 in a collective publication by Kania, Leśniak, and Bomba (2013). The following article will analyse some opinions and attitudes of respondents who, at the time of the survey, were members of cooperatives, and contradict them with opinions and attitudes presented by non-members of cooperatives.

\section{Characteristics of farmers under investigation}

Out of the 2,525 farmers who participated in the study, 835 declared themselves to be members of cooperatives, which amounted to $33 \%$ of the surveyed sample. Members of cooperatives were predominantly male (75.6\%), with women comprising only $24.4 \%$ of the membership. The largest percentage of respondents (63.5\%) who were cooperative members fell into the 41-60 age category. Almost every fifth cooperative member was aged 5155. Compared with the rest of the population of surveyed farmers, cooperative members were somewhat older. It could be said that cooperative membership requires a certain level of maturity. The decision to become a member is usually made by more experienced farmers. It is noticeable that there are very few young members of cooperatives. Only $6.8 \%$ of the surveyed farmers who claimed to be cooperative members were under the age of 30 . Members of cooperatives in the study were somewhat less educated than the rest of the surveyed farmers. Over two thirds of cooperative members had a high school diploma (42\%) or graduated from a vocational school (35.7\%). It should be emphasised here that farmers with university degrees rarely joined cooperatives. Ownership status was rather similar in both groups. The data show that members of cooperatives were more likely to farm rented land (39.4\%) than non-member farmers (33.9\%). All of these characteristics are presented in Table 1. 
Table 1. Characteristics of farmers who participated in the research

\begin{tabular}{|c|c|c|c|}
\hline \multicolumn{2}{|r|}{ Characteristics: } & $\begin{array}{c}\text { Cooperative } \\
\text { members }\end{array}$ & $\begin{array}{l}\text { Non-member } \\
\text { farmers }\end{array}$ \\
\hline \multicolumn{2}{|c|}{ Female } & 24.4 & 35.5 \\
\hline \multicolumn{2}{|c|}{ Male } & 75.6 & 64.5 \\
\hline \multirow{10}{*}{ 政 } & 25 and under & 1.8 & 5.9 \\
\hline & $26-30$ & 5.0 & 8.5 \\
\hline & $31-35$ & 9.1 & 11.7 \\
\hline & $36-40$ & 10.5 & 14.0 \\
\hline & $41-45$ & 13.0 & 13.3 \\
\hline & $46-50$ & 14.3 & 11.6 \\
\hline & $51-55$ & 19.5 & 15.1 \\
\hline & $56-60$ & 16.7 & 12.0 \\
\hline & $61-65$ & 7.8 & 5.7 \\
\hline & 66 and over & 2.3 & 2.2 \\
\hline \multirow{6}{*}{\multicolumn{2}{|c|}{ 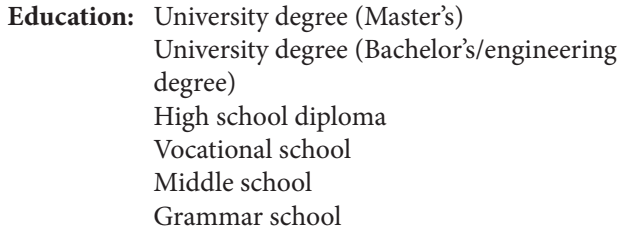 }} & 9.0 & 16.5 \\
\hline & & 6.0 & 9.4 \\
\hline & & 42.0 & 39.9 \\
\hline & & 35.7 & 28.6 \\
\hline & & 0.0 & 0.4 \\
\hline & & 7.3 & 5.2 \\
\hline \multicolumn{4}{|c|}{ Ownership/renting status: } \\
\hline & \multirow{3}{*}{$\begin{array}{l}\text { Agricultural land is owned by farmer } \\
\text { Land partially owned and partially rented } \\
\text { Agricultural land is rented by farmer }\end{array}$} & 52.2 & 50.8 \\
\hline & & 39.4 & 33.9 \\
\hline \multirow{2}{*}{\multicolumn{2}{|c|}{$\begin{array}{l}\text { Agricultural land is rented by farmer } \\
\text { Other }\end{array}$}} & 1.8 & 3.0 \\
\hline & & 6.6 & 12.3 \\
\hline
\end{tabular}

Source: own research.

The importance of farm structure in rural areas was also highlighted by the study. The data in Table II can be useful in providing answers to at least two questions. The first one deals with the size of farms managed by farmers who are cooperative members. The second question addresses the link between cooperative membership and farm size. 
Table 2. Farm operated by research participants

\begin{tabular}{|c|c|c|c|}
\hline Farm size & $\begin{array}{c}\text { Cooperative } \\
\text { members }\end{array}$ & $\begin{array}{c}\text { Farmers who were not cooperative } \\
\text { members }\end{array}$ & Total \\
\hline 1 ha and under & 3.0 & 9.9 & 7.6 \\
\hline $1.01-5$ ha & 6.5 & 12.9 & 10.7 \\
\hline $5.01-10$ ha & 19.1 & 14.8 & 13.3 \\
\hline $10.01-15$ ha & 12.0 & 13.3 & 12.9 \\
\hline $15.01-20$ ha & 13.9 & 11.0 & 11.9 \\
\hline $20.01-50$ ha & 34.7 & 26.4 & 29.2 \\
\hline Over 50.01 ha & 18.7 & 11.8 & 14.4 \\
\hline Total & 100 & 100 & 100 \\
\hline
\end{tabular}

Source: own research.

Out of all respondents who were members of cooperatives, those with farms of 20-50 hectares (ha) comprised $34.7 \%$, while those with 5-10 ha comprised $19.1 \%$. Farms larger than 50 ha were in the hands of $18.7 \%$ of cooperative members, and smaller farms of 10-20 ha were operated by $15.9 \%$ of cooperative members. Only $6.5 \%$ of respondents had farms in the size category of 1-5 ha, and 3\% farmed plots smaller than one hectare. More than half of the farmers (53.4\%) who were members of cooperatives operated farms that were larger than 20 ha. Among those who were not involved in cooperatives, only $38.2 \%$ operated farms larger than 20 ha. The differences in farm sizes operated by members of cooperatives and non-members were quite significant. As indicated, cooperative membership was one of the most meaningful variables influencing farm size. Farmers who were members of cooperatives operated larger farms and were more likely to rent agricultural land, which the data in Table 2 reflect.

\section{Opinions and attitudes presented by farmers}

Cooperatives, as indicated by the name, deal with cooperation, doing things together. Therefore, two of the introductory questions in the survey were meant to verify whether the respondents work with other farmers and engage in various forms of self-help. According to the survey, 55 farmers 
with cooperative membership helped on someone else's farm. When asked about the hypothetical situation of malfunctioning farm equipment and whether they would be able to borrow equipment from another farmer, $71.6 \%$ of the respondents reacted positively and $36 \%$ said that they could easily find such a farmer. This indicated good relations between farmers and a readiness to help each other. Most of them would be able to cooperate out of necessity, perhaps out of willingness, or maybe under guidance of a local leader. Only $1.6 \%$ of farmers with cooperative membership were certain that they could not find such help, and $8.5 \%$ thought that assistance would be difficult to find. There were other answers as well, e.g. $7 \%$ of respondents said that in the event of malfunctioning farm equipment they would use a professional service instead of borrowing from another farmer. It can be assumed that such answers were given by farmers owning or operating very large farms where highly mechanised farm equipment was used. Comparing the attitudes of farmers who are members of cooperatives and those who are not, it is noticeable that the former are more likely to cooperate and help each other. Details related to this issue are presented in Table 3.

Table 3. Respondents' attitudes towards cooperation with other farmers (\%)

\begin{tabular}{|l|c|c|}
\hline Help with farm work and attitudes of respondents & $\begin{array}{c}\text { Cooperative } \\
\text { members }\end{array}$ & $\begin{array}{c}\text { Non- member } \\
\text { farmers }\end{array}$ \\
\hline Did you help with work on someone's farm in exchange & & \\
$\quad$ for help on your farm within the last year? & 55.0 & 41.4 \\
Yes & 42.5 & 55.6 \\
No & 2.5 & 3.0 \\
\hline If your farm equipment stopped working, then: & & \\
I would easily find a farmer who would let me use his & 36.0 & 30.0 \\
equipment & 35.6 & 37.5 \\
I would somehow find such a farmer & 8.5 & 11.9 \\
It would be hard for me to find such a farmer & 1.6 & 2.3 \\
I would certainly not find such a farmer & & \\
I would rent farm equipment from a company that & 7.0 & 4.6 \\
specialises in such services, rather than borrowing & 11.3 & 13.4 \\
equipment from another farmer & & \\
I do not know / It is hard to say & & \\
\hline
\end{tabular}

Source: own research.

To some extent, these findings were confirmed by answers to standard questions about trust. Sceptical attitudes about trust were displayed by more 
than half of the respondents. Almost $63 \%$ of cooperative members and $64 \%$ of non-members said that caution is advised in contact with other people. However, the opposite attitude, summarised by the statement "generally, most people can be trusted", was not uncommon. In this study, it was shared by $24.1 \%$ of respondents. Interestingly, cooperative membership did not have a significant effect on farmers' trust in others. Despite the notion that the cooperative ideal is based on the ability to work together and trust others, only $26.9 \%$ of cooperative members believed that people could be trusted. The difference between answers presented by farmers who were cooperative members and those who were not was almost $4 \%$. Farmers who were cooperative members trusted other people somewhat more. Presumably, a higher level of trust usually facilitates working and cooperating with other people and tends to strengthen entrepreneurial attitudes.

Table 4. Opinions concerning trust in others (\%)

\begin{tabular}{|l|c|c|}
\hline \multicolumn{1}{|c|}{ Opinions of respondents } & $\begin{array}{c}\text { Cooperative } \\
\text { members }\end{array}$ & Non-member farmers \\
\hline Generally, most people can be trusted & 26.9 & 23.0 \\
\hline One should be careful in relations with others & 62.7 & 64.1 \\
\hline I do not know / It is hard to tell & 10.4 & 12.9 \\
\hline Total & 100 & 100 \\
\hline
\end{tabular}

Source: own research.

Another important issue addressed by the study was respondents' state of knowledge on cooperatives. It seems natural to hypothesise that farmers who are cooperative members have more knowledge on cooperative principles and functioning than non-member farmers. The possession of knowledge of cooperative functioning in the past and present was declared by $37.2 \%$ of farmers who had cooperative membership and $22 \%$ of non-member farmers. Every third cooperative member and almost every third nonmember farmer had a general knowledge of cooperative principles and rules. Every fifth cooperative member and every tenth non-member farmer knew the history, ideas and principles of the cooperative movement. It is crucial to the development of the cooperative movement that farmers, and cooperative members in particular, know the benefits connected with cooperative membership. This could be a chance for the cooperative movement in Poland 
to achieve the popularity and respect [domestically] that it enjoys in other parts of the world. Among the respondents, knowledge of cooperative membership benefits was declared by $28.1 \%$ of cooperative members and $16 \%$ of non-members. Legal and economic aspects of cooperatives were generally unknown to both cooperative members and other farmers. Only $8.2 \%$ of cooperative members and $4.2 \%$ of non-member farmers knew legal aspects of cooperative functioning. Familiarity with financing of cooperatives was declared by $13.2 \%$ of cooperative members and $4.5 \%$ of non-members. More than every tenth farmer with no cooperative membership demonstrated a complete lack of knowledge on cooperatives. Table 5 shows the knowledge of cooperative members being somewhat better. Nevertheless, the level of knowledge in both groups was rather low. This should come as a surprise, given that the primary principles of the cooperative movement are education, training, and sharing information on the cooperative movement with people involved in cooperatives. Cooperatives striving to avert the unfavourable tendencies related to the shrinking of the rural cooperative movement in Poland should strive to be more effective in getting their message across to cooperative members and non-members alike.

Table 5. Respondents' knowledge on ideas, history and functioning of cooperatives (\%)

\begin{tabular}{|l|c|c|}
\hline \multirow{2}{*}{ What do you know about cooperatives? } & \multicolumn{2}{|c|}{ Affirmative answers } \\
\cline { 2 - 3 } & $\begin{array}{c}\text { Cooperative } \\
\text { members }\end{array}$ & $\begin{array}{c}\text { Farmers who are not } \\
\text { cooperative members }\end{array}$ \\
\hline
\end{tabular}

Source: own research.

Respondents' opinions on the role and meaning of the cooperative movement to rural development were also studied. Similar to the previous question, the differences of opinions were quite salient between those farmers who were members of cooperatives and those who were not. Over two thirds (68\%) of cooperative members stated that this form of collective organisation and work is helpful to agricultural and rural development. As many as $55.1 \%$ of them thought that cooperatives could economically and socially stimulate rural people, and 54.9\% regarded cooperatives as valuable and necessary to agricultural and rural development. Farmers who were not cooperative members were less generous in their opinions of the cooperative movement. It is worth emphasising that a relatively large percentage of respondents in both groups had not formed an opinion about 
the role of the cooperative movement in rural development. Detailed results are presented in Table 6 .

Table 6. Opinion on contemporary cooperative movement (\%)

\begin{tabular}{|c|c|c|c|c|c|c|}
\hline \multirow{3}{*}{$\begin{array}{c}\text { Opinion } \\
\text { on cooperatives }\end{array}$} & \multicolumn{6}{|c|}{ Responses } \\
\hline & \multicolumn{2}{|c|}{ Yes } & \multicolumn{2}{|c|}{ No } & \multicolumn{2}{|c|}{ No opinion } \\
\hline & $\begin{array}{l}\text { Cooperative } \\
\text { members }\end{array}$ & $\begin{array}{l}\text { Other } \\
\text { farmers }\end{array}$ & $\begin{array}{c}\text { Cooperative } \\
\text { members }\end{array}$ & $\begin{array}{l}\text { Other } \\
\text { farmers }\end{array}$ & $\begin{array}{l}\text { Cooperative } \\
\text { members }\end{array}$ & $\begin{array}{l}\text { Other } \\
\text { farmers }\end{array}$ \\
\hline $\begin{array}{l}\text { Valuable and } \\
\text { necessary for } \\
\text { agricultural } \\
\text { and rural } \\
\text { development }\end{array}$ & 54.9 & 37.4 & 14.1 & 17.3 & 31.0 & 45.3 \\
\hline $\begin{array}{l}\text { Helpful for } \\
\text { increasing } \\
\text { economic } \\
\text { and social } \\
\text { activity in rural } \\
\text { residents }\end{array}$ & 55.1 & 43.7 & 13.9 & 15.1 & 30.8 & 41.2 \\
\hline $\begin{array}{l}\text { Needed for } \\
\text { agricultural } \\
\text { and rural } \\
\text { development }\end{array}$ & 68.2 & 51.6 & 7.2 & 11.2 & 24.5 & 37.1 \\
\hline
\end{tabular}

Source: own research.

Among the last concerns of the following text are the obstacles to development of rural cooperatives listed by farmers who participated in the study. Interestingly, cooperative members and non-member farmers have similar perceptions of the obstacles to further development of the cooperative movement in rural Poland. Closer analysis of Table 7 shows that the diagnoses of both respondent groups are similar. As the most serious obstacles slowing down the development of cooperatives, both identified the following issues: reluctance to cooperate, reluctance to form associations, fear of dishonesty and being cheated, lack of trust in others, and negative historical experiences dating back to the People's Republic of Poland. They also mentioned a lack of leadership, which would be crucial in various stages of cooperative organising, and later when regular activities and work would be conducted. Very few farmers considered the development of the cooperative movement in rural areas to be free of obstacles. 
Table 7. Respondents' opinions on obstacles to cooperative development (\%)*

\begin{tabular}{|c|c|c|}
\hline \multirow[b]{2}{*}{ Obstacles } & \multicolumn{2}{|c|}{ Responses } \\
\hline & $\begin{array}{l}\text { Cooperative } \\
\text { members }\end{array}$ & $\begin{array}{l}\text { Other } \\
\text { farmers }\end{array}$ \\
\hline $\begin{array}{l}\text { Reluctance to cooperate in areas of joint services, } \\
\text { joint use of machines, joint production and sales, } \\
\text { joint responsibility and risks }\end{array}$ & 47.5 & 49.0 \\
\hline Fear of dishonesty and being cheated & 43.8 & 45.5 \\
\hline Reluctance to form associations and to cooperate & 39.3 & 36.7 \\
\hline $\begin{array}{l}\text { Negative farmers' experiences related } \\
\text { to setting up agricultural production } \\
\text { cooperatives after World War II }\end{array}$ & 37.9 & 31.5 \\
\hline $\begin{array}{l}\text { Lack of knowledge about goals, tasks, } \\
\text { and forms of organising, lack of familiarity } \\
\text { with legal regulations on cooperatives }\end{array}$ & 35.3 & 33.1 \\
\hline $\begin{array}{l}\text { Lack of awareness that joint cooperative } \\
\text { operations could be effective }\end{array}$ & 29.9 & 25.3 \\
\hline Lack of trust during sharing of profits & 28.7 & 31.7 \\
\hline Lack of financial resources & 28.0 & 28.7 \\
\hline Lack of leaders (organisers) & 26.4 & 21.6 \\
\hline Inability to see benefits of joint initiatives & 16.6 & 14.3 \\
\hline Lack of trust during task assignment & 16.4 & 16.1 \\
\hline Inability to defend farmers' interests & 10.0 & 9.1 \\
\hline Other obstacles & 1.5 & 1.0 \\
\hline No obstacles found & 0.7 & 2.0 \\
\hline
\end{tabular}

* NOTE: Answers do not add up to $100 \%$ because respondents could give more than one. Source: own research.

Finally, the study revealed that cooperative members were quite optimistic about the future of the areas in which they farmed. While $41.6 \%$ of them believed in a prosperous future for agriculture in Poland, only $36.3 \%$ of non-member farmers shared this belief. The study included farmers who also expressed pessimistic attitudes towards the future of agriculture; $28.9 \%$ of them were cooperative members and $32.2 \%$ were not. 


\section{Conclusions}

Two questions were asked in the introduction to the following paper. The first one dealt with the opinions of cooperative members regarding the development of the cooperative movement in Polish rural areas. The opinions presented by cooperative members and comparing them with those of non-member farmers provided a particularly interesting angle to the study. The second question was to explore whether farmers who were cooperative members had extensive knowledge on cooperatives, which would enable future development of the cooperative movement in Polish rural areas. The answers to both questions were presented and analysed with detailed reference to the study results. Here, some methodology remarks on survey sampling are due. Farmers, who participated in the study, used services provided by extension specialists. Participants who were cooperative members were likely to belong to cooperative banks and dairy cooperatives.

The social demographics of farmers who were cooperative members were as follows:

- the number of men among cooperative members was three times higher than the number of women;

- cooperative members were somewhat older than non-member farmers;

- the percentage of cooperative members with university degrees was lower than the percentage of non-member farmers with such education;

- farmers who were members of cooperatives operated on larger farms and were more likely than others to rent agricultural land;

- farmers with cooperative membership declared readiness to cooperate with other farmers far more often than non-member farmers (the former were also more likely to help each other and had a somewhat higher level of trust in others);

- the level of knowledge on subjects related to history and principles of cooperatives was higher among cooperative members than nonmember farmers;

- in both groups of farmers, the familiarity with the history, functioning and principles of the cooperative movement was very low; 
- cooperative members and non-member farmers perceived the same obstacles hindering cooperative development in rural areas.

The above data indicate that even farmers with cooperative experience lacked sufficient knowledge on issues that make cooperatives successful. Such knowledge could help to promote the cooperative movement in rural areas in the future. If cooperatives want to curtail the unfavourable tendencies related to shrinking of their initiatives in rural Poland, they should be more effective in getting farmers' attention on a wholesale basis, regardless of any given farmers' membership status. Their message needs to be understandable and effectively disseminated.

\section{References}

Brodziński, Z., Leśniak, L. \& Bomba, J., 2015. Stan i perspektywy rozwoju spółdzielczości wiejskiej w Polsce [Status and prospects of development of rural cooperatives in Poland], Kraków, Centrum Doradztwa Rolniczego w Brwinowie Oddział w Krakowie.

Diaz-Foncea M., Marcello, C., 2013. Entrepreneurs and the context of cooperative organizations: A definition of cooperative entrepreneur. Canadian Journal of Administrative Sciences, 30 (4), pp. 238-251. Available at: http://dx.doi. org/10.1002/cjas. 1267

Carlos Morales Gutiérrez C., M., Romero Atela, T. \& Muñoz Dueñas, D., 2005. Comparative Synthesis of 20th Century Agricultural Cooperative Movements in Europe. Journal of Rural Cooperation, 33(1), pp. 47-65.

Chaddad F., R., Cook, M. L., 2004. Understanding New Cooperative Models: An Ownership-Control Rights Typology. Review of Agricultural Economics, 26 (No. 3) (Autumn, 2004), pp. 348-360. Available at: http://dx.doi.org/10.1111/ j.1467-9353.2004.00184.x.

Kania J., Leśniak L. \& Bomba J., (eds), 2013. Spółdzielczość w świadomości rolników i doradców oraz praktyczne wykorzystywanie idei spółdzielczej do rozwoju przedsiębiorczości na obszarach wiejskich [Coopperatives in opinions expressed by farmers and advisers and the practical use of cooperatives in order to develop entrepreneurship in rural areas], Kraków, Centrum Doradztwa Rolniczego w Brwinowie Oddział w Krakowie.

McKee G., J., Wilson W., W., \& Dahl B., 2014. Risk and Return Trade-Offs in Partnering Strategies between Co-ops and IOFs. Agribusiness volume 31 issue 1 on pages 76 to 90. Available at: http://dx.doi.org/10.1002/agr.21391. 
Malec K., 2013. Spółdzielnie wiejskie - stare rozwiązanie szansą na przyszłość? [Rural cooperatives - an old solution for future problems?]. Available at: www. ekonomiaspoleczna.pl/wiadomosc/835272.html, Access: 2015-03-15.

Mooney P.H, 2004. Democratizing Rural Economy: Institutional Friction, Sustainable Struggle and the Cooperative Movement. Rural Sociology 69(1), pp. 76-98. Available at: http://dx.doi.org/10.1526/003601104322919919 .

Valentinov V., 2005. The Organizational Nature of Agricultural Cooperatives: A Perspective from the Farm Problem Theory. Journal of Rural Cooperation, 33(2), pp. 139-151. 